ISSN 1392-3196 / e-ISSN 2335-8947

Zemdirbyste-Agriculture, vol. 101, No. 2 (2014), p. 133-138

DOI 10.13080/z-a.2014.101.017

\title{
The interdependence of mineral nitrogen content in different soil layers of Lithuanian agricultural lands
}

\author{
Jonas ARBAČIAUSKAS, Gediminas STAUGAITIS, Zigmas VAIŠVILA, \\ Jonas MAŽVILA, Tomas ADOMAITIS, Donatas ŠUMSKIS, Lina ŽIČKIENĖ, \\ Jadvyga LUBYTĖ, Romas MAŽEIKA \\ Agrochemical Research Laboratory, Lithuanian Research Centre for Agriculture and Forestry \\ Savanorių 287, Kaunas, Lithuania \\ E-mail: bandymai@agrolab.lt
}

\begin{abstract}
The aim of this work was to investigate the interdependence of mineral nitrogen $\left(\mathrm{N}_{\min }\right)$ content in 0-60 and 0-90 $\mathrm{cm}$ soil layers and in $0-30 \mathrm{~cm}$ soil layer in order to see whether it would be possible to predict the $\mathrm{N}_{\min }$ content in the deeper soil layers based on the $\mathrm{N}_{\min }$ content determined in 0-30 cm soil layer and thus to get a possibility to skip the soil sampling from the deeper layers of soil.

The experiment was carried out in 2009-2012 in 156 monitoring plots of $20 \times 20 \mathrm{~m}$ size located in 63 regions of Lithuania characterized by the different prevailing soil types and the different soil texture: Eastern Lithuania - Arenosols (AR) and Planosols (PL) - sand, Luvisols (LV) and Albeluvisols $(A B)$ - sandy loam and light loam; Central Lithuania - Cambisols (CM) and Luvisols - light loam, loam, medium loam, clay loam and clay; Western Lithuania - Albeluvisols and Luvisols - sandy loam and light loam. The data obtained from the long-term fertilisation experiment conducted in Central Lithuania on the light loam Cambisol were used in this study as well. Soil samples for the determination of $\mathrm{N}_{\text {min }}$ content were taken from 0-30, 30-60 and 60-90 cm soil layers. Higher levels of $\mathrm{N}_{\min }$ were found in the soils of heavier texture as well as in the soils of plots treated once with $\mathrm{N}_{\min }$ fertiliser at the rates not lower than $90 \mathrm{~kg} \mathrm{ha}^{-1}$. Significant correlations were determined between the $\mathrm{N}_{\min }$ content in 0-60 or 0-90 cm soil layers and in 0-30 cm soil layer: in spring $r^{2}=0.837, P<0.01$ and $r^{2}=0.687, P<0.01$, respectively, in autumn $r^{2}=0.833, P<0.01$ and $r^{2}=0.723, P<0.01$, respectively. The ratios of $\mathrm{N}_{\text {min }}$ content (as dependent on the $\mathrm{N}_{\min }$ content in $0-30 \mathrm{~cm}$ soil layer) in the $0-60$ and $0-90 \mathrm{~cm}$ soil layers were calculated; when the content of $\mathrm{N}_{\min }$ in $0-30 \mathrm{~cm}$ soil layer increased from 6 to $12 \mathrm{mg} \mathrm{kg}^{-1}$, the $0-60$ and $0-30 \mathrm{~cm}$ soil layer $\mathrm{N}_{\min }$ content ratio decreased from $0.85 \pm 0.25$ to $0.75 \pm 0.13$ in spring and from $0.87 \pm 0.21$ to $0.82 \pm 0.17$ in autumn. These ratios or regression equations can be used for the calculation of $\mathrm{N}_{\min }$ content in the deeper soil layers based on the available data on the $\mathrm{N}_{\min }$ content in 0-30 cm soil layer. Strong correlations were determined between the nitrate $\mathrm{N}$ and $\mathrm{N}_{\min }$ contents in $0-60$ and $0-90 \mathrm{~cm}$ soil layers in spring and in autumn; the corresponding ratios were calculated. The content of nitrates in soil increases as the $\mathrm{N}_{\min }$ level in soil rises.
\end{abstract}

Key words: fertilisation, $\mathrm{N}_{\min }, \mathrm{N}-\mathrm{NO}_{3}$, sampling depth, soil.

\section{Introduction}

The optimal nitrogen fertilisation rates for agricultural crops, calculated based on the $\mathrm{N}_{\text {min }}\left(\mathrm{N}-\mathrm{NO}_{3}\right.$ $+\mathrm{N}_{-} \mathrm{NH}_{4}$ ) content in soil, are recommended in many countries aiming to ensure the efficient use of nitrogen fertiliser as well as to decrease the environmental pollution with nitrogen compounds (Chen et al., 2006; Eriksen et al., 2008; Rutkowska, Fotyma, 2009). Harrison (1995) noted that soil nitrogen and fertiliser nitrogen are equally important for the plant nutrition; other researchers indicate that soil nitrogen is taken up by the plants more efficiently than the fertiliser-supplied nitrogen - soil nitrogen is more evenly distributed through the soil layers, while the major part of fertiliser nitrogen stays in $0-30 \mathrm{~cm}$ soil layer where the concentration of soil microorganisms is the highest. These microorganisms fix or denitrify the nitrogen compounds supplied by fertiliser. Concentrations of microorganisms in the deeper soil layers are lower; therefore the intensity of nitrogen transformation is lower as well (Stokes et al., 1998).
Since $\mathrm{N}_{\min }$ compounds migrate into the lower layers of soil, the soil samples for $\mathrm{N}_{\text {min }}$ tests are usually taken from 0-60 or 0-90 cm soil layers (Mengel et al., 2006; Rutkowska, Fotyma, 2009). The data obtained from the scientific fertilisation experiments carried out on different soil types (containing different levels of $\mathrm{N}_{\text {min }}$ ) prevailing in Lithuania suggested that soil samples for $\mathrm{N}_{\text {min }}$ tests should be taken before the spring fertilisation from 0-60 cm soil layer for cereal crops and from $0-90 \mathrm{~cm}-$ for hilled crops (Pliupelyte et al., 1986; Staugaitis et al., 2007; 2008; Mažvila et al., 2009). Yet Kuhlman et al. (1989) found out that winter wheat plants consumed the major part of required nitrogen from the arable layer of soil, $25 \%$ - from $30-90 \mathrm{~cm}$ and only $8 \%$ - from $90-150 \mathrm{~cm}$ soil layer. According to the results obtained by the United Kingdom researchers, $50 \%$ of total $\mathrm{N}_{\min }$ available in $0-90$ $\mathrm{cm}$ soil layer was accumulated in $0-30 \mathrm{~cm}$ layer (Stokes et al., 1998). Similar results were obtained in Lithuania: 
$48-49 \%$ of total $\mathrm{N}_{\text {min }}$ available in $0-90 \mathrm{~cm}$ soil layer was accumulated in $0-30 \mathrm{~cm}$ layer (Staugaitis et al., 2008).

Soil sampling from the deeper layers is quite labour-intensive, thus the interdependence of $\mathrm{N}_{\min }$ content in $0-60$ or $0-90 \mathrm{~cm}$ soil layers and in $0-30 \mathrm{~cm}$ soil layer was sought after in order to see whether it would be possible to calculate and adjust the $\mathrm{N}$ fertilisation rates based on the $\mathrm{N}_{\text {min }}$ content determined in the top layer of soil (Knight, 2006).

Changes in mineral nitrogen $\left(\mathrm{NO}_{3}\right.$ and $\left.\mathrm{NH}_{4}\right)$ content in Lithuanian soils amounts in early spring and late autumn, 0-30, 30-60 and 60-90 cm soil layers were monitored since 1984 in the long-term scientific fertilisation experiment and since 2005 - in the selected monitoring plots located in the representative soil regions of the Eastern, Central and Western Lithuania. Based on the results obtained, the agricultural producers were provided with the appropriately adjusted and environmentallyresponsible nitrogen fertilisation recommendations. During all these years the need to decrease the labour-intensiveness of soil sampling activities became quite obvious.

The aim of our study was to process the accumulated scientific data and to calculate the interdependence of mineral nitrogen $\left(\mathrm{N}_{\min }\right)$ content in $0-60$ or $0-90 \mathrm{~cm}$ soil layers and the $\mathrm{N}_{\text {min }}{ }^{\min }$ content in $0-30 \mathrm{~cm}$ soil layer.

\section{Materials and methods}

Mineral nitrogen $\left(\mathrm{N}_{\text {min }}\right)$ tests were carried out in 2009-2012 in 156 plots of $20 \times 20 \mathrm{~m}$ size located in 63 regions of Lithuania, representing the main soils of different texture: Eastern Lithuania - Arenosols $(A R)$ and Planosols (PL) - sand, Luvisols (LV) and Albeluvisols $(A B)$ - sandy loam and light loam; Central Lithuania Cambisols (CM) and Luvisols - light loam, loam, medium loam, clay loam and clay; Western Lithuania-Albeluvisols and Luvisols - sandy loam and light loam (Fig. 1). Annual precipitation during the experimental years slightly (5$11 \%$ ) exceeded the multiannual average.

The data obtained from the long-term fertilisation experiment conducted in Central Lithuania on the light loam Cambisol were used for the purposes of this study as well. The plots were occupied with winter wheat, spring rape, spring barley and annual grasses (vetch-oat mixture). Plots were fertilised with $0,30,60,90$ and 180 $\mathrm{kg} \mathrm{ha}^{-1} \mathrm{~N}$ rates on the different backgrounds of phosphorus

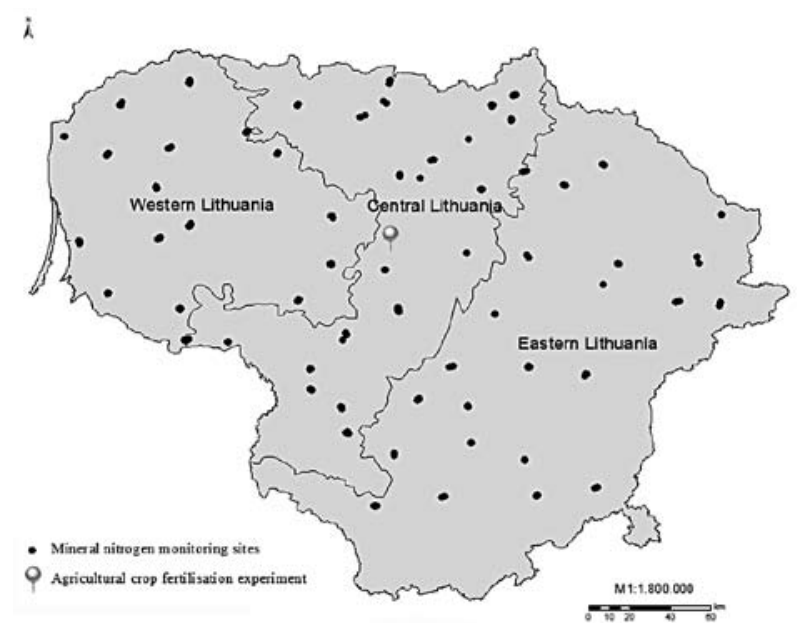

Figure 1. Locations of soil sampling for mineral nitrogen $\left(\mathrm{N}_{\min }\right)$ tests and potassium fertiliser rates. Soil sampling for $\mathrm{N}_{\text {min }}$ tests was carried out in spring and in autumn from 0-30, 30-60 and $60-90 \mathrm{~cm}$ layers of soil. Grouping of the taken soil samples according to the soil texture was the following: in spring - 306 from the sandy soils, 1347 from the sandy loam and light loam soils, 207 from the medium loam, clay loam and clay soils; in autumn - 288, 1317 and 207 samples, respectively. Soil $\mathrm{N}_{\min }$ was expressed as the total nitrogen of $\mathrm{N}-\mathrm{NH}_{4}$ and $\mathrm{N}-\mathrm{NO}_{3}$ determined in the $1 \mathrm{M} \mathrm{KCl}$ extraction. The ratios of $\mathrm{N}_{\text {min }}^{3}$ content in different layers of soil were calculated by dividing the amount of $\mathrm{N}_{\min }$ determined in $0-60$ and $0-90 \mathrm{~cm}$ soil layers by the $\mathrm{N}_{\min }$ amount determined in $0-30 \mathrm{~cm}$ soil layer. The arithmetical means were calculated for each of the groups (grouping was based on the $\mathrm{N}_{\text {min }}$ content in 0-30 cm soil layer).

The obtained data were evaluated statistically by calculating the standard deviations and the correlative - regressive relations expressed in the coefficients of determination $r^{2}$; the significance was evaluated using $t$ test $-P$ with the help of software STATISTICA 7 (Clewer, Scarisbric, 2001).

\section{Results and discussion}

Mineral nitrogen $\left(\mathrm{N}_{\text {min }}\right)$ content in soil is closely related to the $\mathrm{N}$ balance and its transformation processes depending on the $\mathrm{C}: \mathrm{N}$ ratio, concentration and activity of the microorganisms, soil properties as well as weather conditions (Koos, Nemeth, 2006; Marchetti, Castelli, 2011). Major part of the $\mathrm{N}$ is supplied to the soil with organic and mineral fertilisers; the rest of it comes from the atmosphere and is fixed biologically (Staugaitis et al., 2007; McConnell et al., 2011; Wang et al., 2012). Mineral nitrogen content in soil increases substantially when crops are treated with $180-200 \mathrm{~kg} \mathrm{ha}^{-1}$ and higher rates of N (Bergstrëm, Brink, 1986; Mažvila et al., 2009).

The data obtained from our experiments suggest that $\mathrm{N}_{\min }$ content in $0-60 \mathrm{~cm}$ soil layer was low: $6.37 \pm$ $3.13 \mathrm{mg} \mathrm{kg}^{-1}$ in spring and $6.63 \pm 4.12 \mathrm{mg} \mathrm{kg}^{-1}$ in autumn (Table 1). The lowest levels of $\mathrm{N}_{\min }$ were determined in sandy soils, average - in loamy sand and sandy loam soils, high - in medium loam, clay loam and clay soils. Chen et al. (2007) noted that higher content of clay particles slows down the migration of nitrates in soil. Bednarek and Reszka (2008) and Rutkowska and Fotyma (2009) have also found that heavier-textured soils contain larger $\mathrm{N}_{\text {min }}$ amounts. The data obtained from our experiments suggest that the highest $\mathrm{N}_{\min }$ concentration is in $0-30 \mathrm{~cm}$ soil layer, followed by the lower levels in $30-60 \mathrm{~cm}$ soil layer and the lowest - in 60-90 cm soil layer. The ratios were calculated aiming to determine the interdependence of $\mathrm{N}_{\text {min }}$ content in $0-60$ and $0-90 \mathrm{~cm}$ and $0-30 \mathrm{~cm}$ soil layers. It was found that these ratios did not depend significantly enough on the soil texture with only one exception: in autumn the relatively higher levels of $\mathrm{N}_{\text {min }}$ are accumulated in the lower soil layers of light-textured soils, and in spring - in the lower soil layers of heavytextured soils.

According to the results obtained from the long-term experiment, the $\mathrm{N}_{\min }$ content in $0-60 \mathrm{~cm}$ soil layer in autumn depended on the applied $\mathrm{N}$ fertilisation rates and was within the range of $5.18 \pm 2.86-11.5 \pm$ $4.75 \mathrm{mg} \mathrm{kg}^{-1}$. Content of $\mathrm{N}$ increased substantially when the plants were treated with onetime $90 \mathrm{~kg} \mathrm{ha}^{-1}$ and higher $\mathrm{N}$ rates (Table 2). When plants were treated with the $\mathrm{N}$ rates below $90 \mathrm{~kg} \mathrm{ha}^{-1}$, the highest $\mathrm{N}_{\text {min }}$ concentration was 
Table 1. Mineral nitrogen $\left(\mathrm{N}_{\min }\right)$ content in the soils of different texture and the ratios of $\mathrm{N}_{\min }$ content between the deeper soil layers and the upper soil layer, 2009-2012

\begin{tabular}{cccccc}
\hline \multicolumn{2}{c}{ Soil sampling } & Sand & Sandy loam, light loam & Medium loam, clay loam, clay & Mean \\
\hline $\begin{array}{c}\text { Soil layer } \\
\text { cm }\end{array}$ & season & & \multicolumn{2}{c}{ Soil $\mathrm{N}_{\text {min }} \pm \mathrm{SD} \mathrm{mg} \mathrm{kg}^{-1}$} & \\
\hline \multirow{2}{*}{$0-30$} & spring & $6.66 \pm 3.39$ & $8.13 \pm 4.18$ & $8.72 \pm 5.84$ & $7.96 \pm 4.31$ \\
& autumn & $6.74 \pm 3.36$ & $8.21 \pm 5.12$ & $9.73 \pm 6.14$ & $8.18 \pm 5.09$ \\
\hline \multirow{2}{*}{$30-60$} & spring & $4.21 \pm 2.51$ & $4.76 \pm 2.86$ & $5.89 \pm 3.72$ & $4.80 \pm 2.94$ \\
& autumn & $4.58 \pm 3.68$ & $4.99 \pm 3.73$ & $6.25 \pm 4.44$ & $5.08 \pm 3.83$ \\
\hline \multirow{2}{*}{$60-90$} & spring & $3.92 \pm 2.70$ & $4.26 \pm 2.78$ & $4.88 \pm 3.37$ & $4.27 \pm 2.85$ \\
& autumn & $3.81 \pm 3.30$ & $3.63 \pm 2.46$ & $4.10 \pm 2.54$ & $3.71 \pm 2.61$ \\
\hline \multirow{2}{*}{$0-60$} & spring & $5.44 \pm 2.57$ & $6.45 \pm 2.97$ & $7.31 \pm 4.42$ & $6.37 \pm 3.13$ \\
& autumn & $5.65 \pm 3.16$ & $6.60 \pm 4.06$ & $6.50 \pm 3.84$ & $5.63 \pm 4.12$ \\
\hline \multirow{2}{*}{$0-90$} & spring & $4.93 \pm 2.38$ & $5.72 \pm 2.62$ & $6.69 \pm 3.98$ & $5.66 \pm 3.41$ \\
\hline \multirow{2}{*}{$0-60$} & autumn & $5.04 \pm 3.04$ & $5.61 \pm 3.34$ & $0.84 \pm 0.22$ & $0.82 \pm 0.18$ \\
& Ratios between the $\mathrm{N}_{\text {min }}$ available in deeper soil layers and the $0-30$ cm soil layer $\pm \mathrm{SD}$ & $0.85 \pm 0.15$ \\
\hline \multirow{2}{*}{$0-90$} & spring & $0.82 \pm 0.17$ & $0.82 \pm 0.17$ & $0.83 \pm 0.11$ & $0.73 \pm 0.23$ \\
& autumn & $0.86 \pm 0.16$ & $0.84 \pm 0.16$ & $0.75 \pm 0.24$ & $0.73 \pm 0.18$ \\
\hline
\end{tabular}

$\mathrm{SD}$ - standard deviation

Table 2. Mineral nitrogen $\left(\mathrm{N}_{\min }\right)$ content in soil as affected by the nitrogen fertilisation rates

Skèmiai, Radviliškis distr., 2009-2012

\begin{tabular}{ccccccc}
\hline \multirow{2}{*}{$\begin{array}{c}\text { Nitrogen } \\
\text { fertilisation rate } \\
\mathrm{kg} \mathrm{ha}^{-1}\end{array}$} & $\begin{array}{c}\text { Soil } \\
\text { sampling }\end{array}$ & time & \multicolumn{5}{c}{ Soil sampling depth cm } \\
\cline { 3 - 7 } & spring & $6.62 \pm 3.73$ & $3.72 \pm 2.44$ & $2.55 \pm 1.53$ & $5.18 \pm 2.86$ & $4.30 \pm 2.25$ \\
\multirow{2}{*}{0} & autumn & $5.21 \pm 1.93$ & $2.80 \pm 1.12$ & $2.26 \pm 1.04$ & $4.01 \pm 1.47$ & $3.42 \pm 1.29$ \\
\hline \multirow{2}{*}{30} & spring & $6.60 \pm 0.54$ & $4.19 \pm 0.35$ & $3.01 \pm 0.91$ & $5.40 \pm 0.36$ & $4.60 \pm 0.53$ \\
& autumn & $5.83 \pm 0.77$ & $3.66 \pm 0.29$ & $3.00 \pm 0.64$ & $4.74 \pm 0.38$ & $4.16 \pm 0.27$ \\
\hline \multirow{2}{*}{60} & spring & $6.60 \pm 1.27$ & $4.52 \pm 1.17$ & $2.72 \pm 0.95$ & $5.56 \pm 1.13$ & $4.62 \pm 0.97$ \\
& autumn & $5.85 \pm 1.17$ & $3.84 \pm 0.72$ & $2.81 \pm 0.59$ & $4.84 \pm 0.89$ & $4.16 \pm 0.75$ \\
\hline \multirow{2}{*}{90} & spring & $9.03 \pm 5.25$ & $7.83 \pm 4.30$ & $4.28 \pm 1.93$ & $8.35 \pm 4.48$ & $6.46 \pm 2.34$ \\
& autumn & $6.25 \pm 2.34$ & $4.68 \pm 2.68$ & $3.71 \pm 1.64$ & $5.46 \pm 2.39$ & $4.88 \pm 1.97$ \\
\hline \multirow{2}{*}{180} & spring & $9.81 \pm 4.12$ & $13.2 \pm 7.17$ & $8.52 \pm 4.30$ & $11.5 \pm 4.75$ & $10.5 \pm 4.13$ \\
& autumn & $8.49 \pm 3.16$ & $7.30 \pm 3.55$ & $7.17 \pm 3.14$ & $7.89 \pm 2.98$ & $7.66 \pm 2.53$ \\
\hline
\end{tabular}

SD - standard deviation

determined in 0-30 $\mathrm{cm}$ soil layer, followed by the lower levels in 30-60 cm soil layer and the lowest - in 60-90 $\mathrm{cm}$ soil layer. When plants were treated with $180 \mathrm{~kg} \mathrm{ha}^{-1}$ $\mathrm{N}$ rate, the highest levels $\left(13.2 \pm 7.17 \mathrm{mg} \mathrm{kg}^{-1}\right)$ of $\mathrm{N}_{\min }$ were determined in 30-60 $\mathrm{cm}$ soil layer due to the nitrate migration. According to the findings of Lopez-Bellindo et al. (2013), when plants are treated with high $\mathrm{N}$ rates $\left(150 \mathrm{~kg} \mathrm{ha}^{-1}\right)$, the nitrates migrate from the arable layer of soil, which causes an increase of nitrate concentration in $30-60 \mathrm{~cm}$ soil layer.

According to the results of the experiments conducted on sandy loams in United Kingdom, the application of high $\mathrm{N}$ rates resulted in high losses of $\mathrm{N}_{\min }$ in spring compared to the $\mathrm{N}_{\min }$ amounts left in soil in autumn (Bhogal et al., 2000). The data obtained from our long-term experiment on the $\mathrm{N}_{\min }$ content in 0-60 cm soil layer in spring and autumn revealed the decrease of $\mathrm{N}_{\min }$ content in spring as well; the degree of this decrease depended on the nitrogen fertilisation rate applied in spring and was from $4.74 \pm 0.38$ to $7.89 \pm 2.98 \mathrm{mg} \mathrm{kg}^{-1}$ (Table 2). Higher losses of $\mathrm{N}_{\min }$ were determined in the plots where $\mathrm{N}_{\min }$ levels in autumn were high. Both in spring and autumn higher levels of $\mathrm{N}_{\min }$ were determined in $0-30 \mathrm{~cm}$ soil layer except for the plots treated with
$180 \mathrm{~kg} \mathrm{ha}^{-1} \mathrm{~N}$ rates - here high levels of $\mathrm{N}_{\min }$ were determined in 60-90 cm soil layer as well.

The data obtained from our experiments suggest that nitrogen migration in soil depends on the season and $\mathrm{N}$ fertilisation intensity; nitrogen compounds distribute in the soil layers unevenly. In order to determine the regularities of $\mathrm{N}_{\min }$ distribution in different soil layers in spring and autumn, the correlations and interrelations between the $\mathrm{N}_{\min }$ contents in 0-60 and 0-90 cm soil layers and 0-30 cm soil layer were calculated. Significant correlation was determined between the $\mathrm{N}_{\text {min }}$ content in $0-60$ and $0-30 \mathrm{~cm}$ soil layers in spring $-r^{2} \stackrel{\min }{=} 0.837, P<0.01$ (Fig. 2) and somewhat less significant - between the $\mathrm{N}_{\min }$ content in $0-90$ and $0-30 \mathrm{~cm}$ soil layers $-r^{2}=0.687, \stackrel{\min }{P}<0.01$. The corresponding calculations for autumn were $r^{2}=0.833$, $P<0.01$ and $r^{2}=0.723, P<0.01$, respectively.

The data on $\mathrm{N}_{\min }$ content in soil were grouped according to the evaluation scale used in Lithuania at present (Pliupelyte et al., 1986; Staugaitis et al., 2007). It was found that the comparative values of $\mathrm{N}_{\text {min }}$ content in $0-60$ and $0-90 \mathrm{~cm}$ (as compared to the $\mathrm{N}_{\min }^{\min }$ content in $0-30 \mathrm{~cm}$ soil layer) in spring as well as in autumn were higher when the soils were richer in $\mathrm{N}_{\text {min }}$ (Table 3). Autumn values were higher than the spring values. 

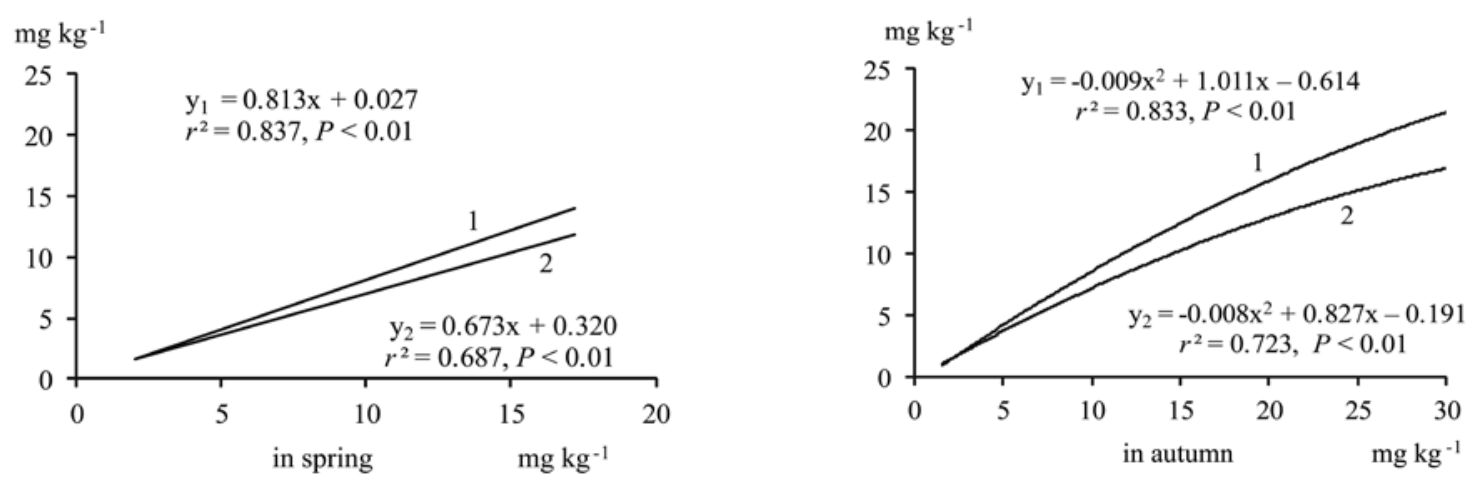

Figure 2. Correlation between the mineral nitrogen contents in 0-60 ( $\left.\mathrm{y}_{1}\right)$ and $0-90\left(\mathrm{y}_{2}\right) \mathrm{cm}$ soil layers and in 0-30 cm soil layer $(\mathrm{x})$

Table 3. Comparative values of mineral nitrogen $\left(\mathrm{N}_{\min }\right)$ content in different soil layers as affected by the $\mathrm{N}_{\min }$ content in $0-60 \mathrm{~cm}$ layer of soil

\begin{tabular}{|c|c|c|c|c|}
\hline \multirow{2}{*}{ Season } & \multicolumn{3}{|c|}{$\mathrm{N}_{\min }$ content $\mathrm{mg} \mathrm{kg}^{-1}$ in $0-60 \mathrm{~cm}$ soil layer } & \multirow{2}{*}{ Mean } \\
\hline & $<5$ & $5-10$ & $>10$ & \\
\hline \multicolumn{5}{|c|}{ Comparative values of $\mathrm{N}_{\min }$ content in $0-60$ and $0-30 \mathrm{~cm}$ soil layers $\pm \mathrm{SD}$} \\
\hline Spring & $0.78 \pm 0.13$ & $0.83 \pm 0.18$ & $0.86 \pm 0.15$ & $0.82 \pm 0.20$ \\
\hline Autumn & $0.79 \pm 0.14$ & $0.85 \pm 0.21$ & $0.92 \pm 0.22$ & $0.86 \pm 0.24$ \\
\hline \multicolumn{5}{|c|}{ Comparative values of $\mathrm{N}_{\min }$ content in $0-90$ and $0-30 \mathrm{~cm}$ soil layers $\pm \mathrm{SD}$} \\
\hline Spring & $0.70 \pm 0.21$ & $0.75 \pm 0.24$ & $0.76 \pm 0.17$ & $0.73 \pm 0.23$ \\
\hline Autumn & $0.69 \pm 0.20$ & $0.74 \pm 0.28$ & $0.76 \pm 0.24$ & $0.73 \pm 0.26$ \\
\hline
\end{tabular}

$\mathrm{SD}$ - standard deviation

The qualified groups of soil richness in mineral nitrogen based on the $\mathrm{N}_{\min }$ content determined in $0-30 \mathrm{~cm}$ soil layer were made using the comparative values of $\mathrm{N}_{\min }$ content in $0-60$ and $0-30 \mathrm{~cm}$ soil layers. In this case, as the levels of $\mathrm{N}_{\min }$ in $0-30 \mathrm{~cm}$ soil layer increased, the comparative values of $\mathrm{N}_{\min }$ levels in 0-60 and 0-90 $\mathrm{cm}$ soil layers decreased. The comparative values between 0-90 and $0-30 \mathrm{~cm}$ soil layers were lower than those between 0-60 and 0-30 $\mathrm{cm}$ soil layers (Table 4).

Table 4. Comparative values of mineral nitrogen $\left(\mathrm{N}_{\min }\right)$ content in different soil layers as affected by the $\mathrm{N}_{\min }$ content in $0-30 \mathrm{~cm}$ layer of soil

\begin{tabular}{|c|c|c|c|c|}
\hline \multirow{2}{*}{ Season } & \multicolumn{3}{|c|}{$\mathrm{N}_{\min }$ content $\mathrm{mg} \mathrm{kg}^{-1}$ in $0-30 \mathrm{~cm}$ soil layer } & \multirow{2}{*}{ Mean } \\
\hline & $<6$ & $6-12$ & $>12$ & \\
\hline \multicolumn{5}{|c|}{ Comparative values of $\mathrm{N}_{\min }$ content in $0-60$ and $0-30 \mathrm{~cm}$ soil layers $\pm \mathrm{SD}$} \\
\hline Spring & $0.85 \pm 0.25$ & $0.83 \pm 0.17$ & $0.75 \pm 0.13$ & $0.82 \pm 0.20$ \\
\hline Autumn & $0.87 \pm 0.21$ & $0.87 \pm 0.25$ & $0.82 \pm 0.17$ & $0.86 \pm 0.23$ \\
\hline \multicolumn{5}{|c|}{ Comparative values of $\mathrm{N}_{\min }$ content in $0-90$ and $0-30 \mathrm{~cm}$ soil layers $\pm \mathrm{SD}$} \\
\hline Spring & $0.78 \pm 0.26$ & $0.75 \pm 0.20$ & $0.64 \pm 0.16$ & $0.73 \pm 0.23$ \\
\hline Autumn & $0.78 \pm 0.27$ & $0.75 \pm 0.26$ & $0.66 \pm 0.18$ & $0.73 \pm 0.26$ \\
\hline
\end{tabular}

SD - standard deviation

In the cases of significant correlations between the $\mathrm{N}_{\text {min }}$ contents in $0-60$ or $0-90 \mathrm{~cm}$ and $0-30 \mathrm{~cm}$ soil layers the regression equations presented in Figure 2 or the comparative values presented in Table 4 can be used for the calculation of $\mathrm{N}_{\min }$ content in $0-60$ or $0-90 \mathrm{~cm}$ soil layers based on the available data on $\mathrm{N}_{\text {min }}$ content in 0-30 soil layer. According to the results of research conducted in Argentina, the correlation between the $\mathrm{N}_{\text {min }}$ contents in $0-60$ and $0-30 \mathrm{~cm}$ soil layers was significant; the researchers came to the conclusion that it is possible to calculate the $\mathrm{N}_{\text {in }}$ content in $0-60 \mathrm{~cm}$ soil layer based on the available data on $\mathrm{N}_{\min }$ content in 0-30 soil layer (Alvarez et al., 2001). The major part of $\mathrm{N}_{\min }$ consists of nitrate anions which are more mobile than ammonium cations; therefore it is important to determine the content of them in autumn and to evaluate the possible leaching during the autumn-winter season. The calculations of correlations between the nitrate $\mathrm{N}$ and the $\mathrm{N}_{\min }$ content in soil conducted in Lithuania revealed that these correlations were very strong in autumn $(0-60$ and $0-90 \mathrm{~cm}$ soil layers $-r^{2}=0.954, P<0.01$ and $r^{2}=0.937, P<0.01$, respectively) and less strong in spring $\left(r^{2}=0.934, P<0.01\right.$ and $r^{2}=$ $0.920, P<0.01$, respectively) (Fig. 3).

The soils were grouped according to the $\mathrm{N}_{\min }$ content in $0-30 \mathrm{~cm}$ soil layer and the nitrate $\mathrm{N}$ and $\mathrm{N}_{\min }$ comparative values were calculated. These values increased both in spring and autumn as the content of in $0-30 \mathrm{~cm}$ soil layer increased (Table 5). Spring values were lower than the autumn values. During the autumnspring season larger amounts of nitrates were leached from the soils containing more than $6 \mathrm{mg} \mathrm{kg}^{-1}$ of $\mathrm{N}_{\min }$ in 0-30 cm soil layer, thus the high content of $\mathrm{N}_{\min }$ in the upper soil layer in autumn indicates the higher amounts of the nitrates as well - there is high possibility of nitrate leaching during the autumn-spring season. 

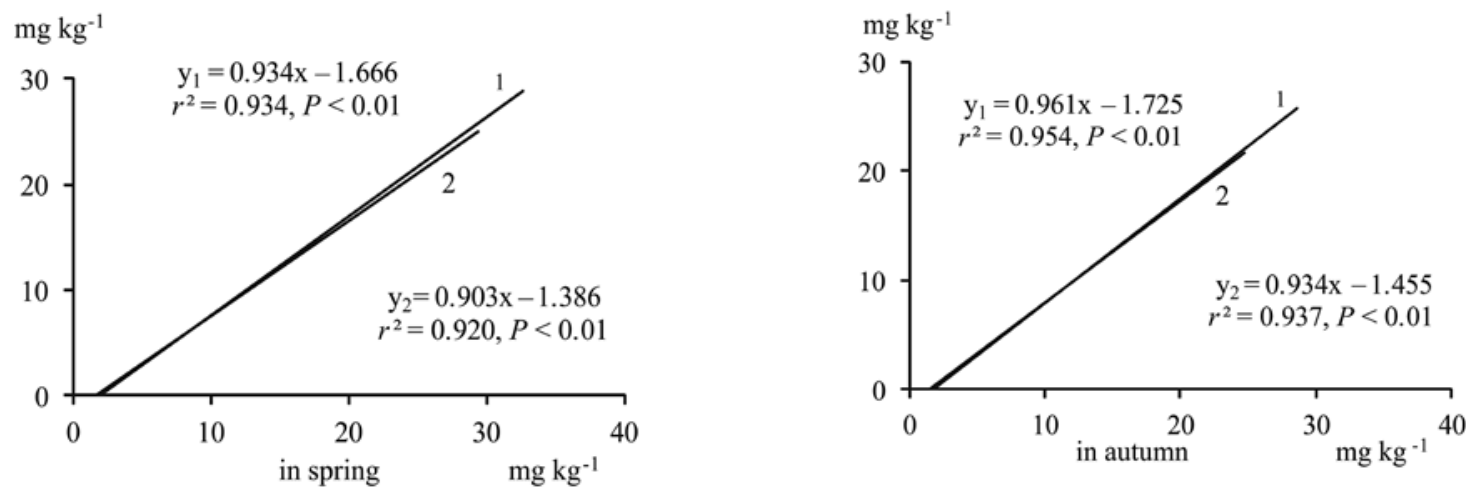

Figure 3. Correlation between nitrate nitrogen content in $0-60\left(\mathrm{y}_{1}\right)$ and $0-90\left(\mathrm{y}_{2}\right) \mathrm{cm}$ soil layers and the mineral nitrogen content

Table 5. Comparative values of nitrate nitrogen and mineral nitrogen $\left(\mathrm{N}_{\min }\right)$ content in soil as affected by the $\mathrm{N}_{\min }$ content in $0-30 \mathrm{~cm}$ layer of soil

\begin{tabular}{|c|c|c|c|c|}
\hline \multirow{2}{*}{ Season } & \multicolumn{3}{|c|}{$\mathrm{N}_{\min }$ content $\mathrm{mg} \mathrm{kg}^{-1}$ in $0-30 \mathrm{~cm}$ soil layer } & \multirow{2}{*}{ Mean } \\
\hline & $<6$ & $6-12$ & $>12$ & \\
\hline \multicolumn{5}{|c|}{ Comparative values of nitrate nitrogen and $\mathrm{N}_{\min }$ content in $0-60 \mathrm{~cm}$ soil layer $\pm \mathrm{SD}$} \\
\hline Autumn & $0.49 \pm 0.22$ & $0.71 \pm 0.21$ & $0.83 \pm 0.12$ & $0.68 \pm 0.25$ \\
\hline Spring & $0.46 \pm 0.21$ & $0.66 \pm 0.22$ & $0.79 \pm 0.14$ & $0.64 \pm 0.24$ \\
\hline \multicolumn{5}{|c|}{ Comparative values of nitrate nitrogen and $\mathrm{N}_{\min }$ content in $0-90 \mathrm{~cm}$ soil layer $\pm \mathrm{SD}$} \\
\hline Autumn & $0.47 \pm 0.23$ & $0.67 \pm 0.23$ & $0.79 \pm 0.19$ & $0.64 \pm 0.25$ \\
\hline Spring & $0.45 \pm 0.22$ & $0.63 \pm 0.21$ & $0.75 \pm 0.20$ & $0.61 \pm 0.24$ \\
\hline
\end{tabular}

$\mathrm{SD}$ - standard deviation

The calculated correlations between the nitrate $\mathrm{N}$ content in $0-60$ and $0-90 \mathrm{~cm}$ soil layers and $0-30 \mathrm{~cm}$ soil layer were strong both in spring $\left(\mathrm{y}=0.002 \mathrm{x}^{2}+0.846 \mathrm{x}\right.$ $-0.125, r^{2}=0.879, P<0.01$ and $\mathrm{y}=0.004 \mathrm{x}^{2}+0.79 \mathrm{x}-$ $\left.0.190, r^{2}=0.756, P<0.01\right)$ and autumn $\left(\mathrm{y}=0.002 \mathrm{x}^{2}+\right.$ $0.914 \mathrm{x}-0.067, r^{2}=0.814, P<0.01$ and $\mathrm{y}=0.003 \mathrm{x}^{2}+$ $\left.0.756 \mathrm{x}-0.039, r^{2}=0.714, P<0.01\right)$. Nitrate $\mathrm{N}$ content in $0-60$ or $0-90 \mathrm{~cm}$ soil layers can be calculated based on the available data on nitrate $\mathrm{N}$ content in $0-30$ soil layer using the coefficients of regression equations; in the cases of strong correlation between the nitrate $\mathrm{N}$ and $\mathrm{N}_{\min }$ contents in soil in spring and autumn the nitrate $\mathrm{N}$ content in $0-60$ or $0-90 \mathrm{~cm}$ soil layers can be calculated based on the available data on content in 0-30 soil layer.

\section{Conclusions}

1. High correlation was determined between the mineral nitrogen $\left(\mathrm{N}_{\min }\right)$ content in 0-60 and 0-90 cm soil layers and in $0-30 \mathrm{~cm}$ soil layer of the prevailing soil types in Lithuania. The regression equations or the calculated comparative values can be used for the calculation of $\mathrm{N}_{\text {min }}$ content in $0-60$ or $0-90 \mathrm{~cm}$ soil layers based on the available data on $\mathrm{N}_{\min }$ content in $0-30$ soil layer.

2. Strong correlation was determined between the nitrate $\mathrm{N}$ and $\mathrm{N}_{\min }$ content in soil; the comparative values were calculated. The level of nitrates in soil is higher when soil contains larger amounts of $\mathrm{N}_{\min }$. Nitrate $\mathrm{N}$ content in $0-60$ or $0-90 \mathrm{~cm}$ soil layers can be calculated based on the available data on nitrate $\mathrm{N}$ content in 0-30 soil layer using the coefficients of regression equations; in the cases of strong correlation between the nitrate $\mathrm{N}$ and $\mathrm{N}_{\min }$ contents in soil in spring and autumn the nitrate $\mathrm{N}$ content in $0-60$ or $0-90 \mathrm{~cm}$ soil layers can be calculated based on the available data on $\mathrm{N}_{\min }$ content in 0-30 soil layer.

Received 12072013 Accepted 21032014

\section{References}

Alvarez C. R., Alvarez R., Steinbach H. S. 2001. Prediction of available nitrogen content in soil profile depth using available nitrogen concentration in surface layer. Communications in Soil Science and Plant Analvsis. 32 (5): 759-769 http://dx.doi.org/10.1081/CSS-100103907

Bednarek W., Reszka K. 2008. Intluence of liming and mineral fertilization on the content of mineral nitrogen in soil. Journal of Elementology, 13 (3): 301-308 (in Polish)

Bergstrëm L., Brink N. 1986. Effects of different applications of fertilizer $\mathrm{N}$ on leaching losses and distribution of inorganic $\mathrm{N}$ in the soil. Plant and Soil. 93: 333-345 http://dx.doi.org/10.1007/BF02374284

Bhogal A., Rochtord A. D., Sylvester-Bradley R. 2000. Net changes in soil and crop nitrogen in relation to the performance of winter wheat given wide-ranging annual nitrogen applications at Ropsley, UK. Journal of Agricultural Science. 135: 139-149 http://dx.doi.org/10.1017/S0021859699008035

Chen X., Zhang F., Romsheld V., Horlader D., Shulz R., BoningZilkens M, Wang P., Claupein W. 2006. Synchronizing N supply from soil and fertilizer and $\mathrm{N}$ demand of winter wheat by improved $\mathrm{N}_{\text {min }}$ method. Nutrient Cycling in Agroecosystems, 74 (2): $: 91-98$ http://dx.doi.org/10.1007/s10705-005-1701-9

Chen X., Wu H., Wo F. 2007. Nitrate vertical transport in the main paddy soils of Tai Lake region, China. Geoderma, 142: 136-141 http://dx.doi.org/10.1016/j.geoderma.2007.08.004

Clewer A. G., Scarisbrick D. H. 2001. Practical statistics and experimental design for plant and crop science. Chichester, UK, 293 p.

Eriksen J., Askergaard M., Søegaard K. 2008. Residual effect and nitrate leaching in grass-arable rotations: effect of grassland proportion, sward type and fertilization. Soil Use and Management. 24: 373-382 http://dx.doi.org/10.1111/j.1475-2743.2008.00178.x

Harrison R. 1995. An investigation of the relationship between soil mineral nitrogen in the autumn or spring and optimum nitrogen rate for winter cereals. Soil Use and Management, 11: 186-192

http://dx.doi.org/10.1111/j.1475-2743.1995.tb00954.x 
Koos S., Nemeth T. 2006. Seasonal dynamics of mineral nitrogen in the $10^{\text {th }}$ and $30^{\text {th }}$ years of long term field experiment in Hungary. Communications in Soil Science and Plant Analvsis. 37: 2899-2909 http://dx.doi.org/10.1080/00103620600832878

Knight S. M. 2006. Soil mineral nitrogen testing: practice and interpretation. Research Review, 58: 1-32

Kuhlman H., Barraclough P. B., Weir A. H. 1989. Utilization of mineral nitrogen in thesubsoil by winter wheat. Zeitshchrift Pflanzenernährung und Bodenkunde, 152: 291-295 http://dx.doi.org/10.1002/jpln.19891520305

Lopez-Bellindo L., Munoz-Romero V., Lopez-Bellindo R. J. 2013. Nitrate accumulation in the soil profile: long-term effects of tillage, rotation and $\mathrm{N}$ rate in a Mediterranean Vertisol. Soil and Tillage Research, 130: 18-23 http://dx.doi.org/10.1016/j.still.2013.02.002

Marchetti R., Castelli F. 2011. Mineral nitrogen dynamics in soil during sugar beet and winter wheat crop grown. European Journal Agronomv. 35: 13-21 http://dx.doi.org/10.1016/j.eja.2011.03.003

Mažvila J., Arbačiauskas J., Antanaitis A., Lubyte J., Adomaitis T. Vaišvila Z. 2009. Effects of long-term fertilization on soil agrochemical properties. ZemdirbysteAgriculture, 96 (2): 35-52 (in Lithuanian)

McConnell J. S., McConnell R. M., Xiaoping P., Altfillisch Ch. J., Gidda K. P., McConnell M.S., Morgan L. R., Mullins B. M., Nicioli S. M., Pedigo T. M., Ribordy K. E., Sheppard D. R. 2011. Suspending nitrogen fertilization reduces residual soil nitrates in dryland cotton. Communications in Soil Science and Plant Analysis, 42: 1223-1230 http://dx.doi.org/10.1080/00103624.2011.566966
Mengel K., Hütsch B., Kane Y. 2006. Nitrogen fertilizer application rates on cereal crops according to available mineral and organic soil nitrogen. European Journal of Agronomv. 24: 343-348 http://dx.doi.org/10.1016/j.eja.2005.12.001

Pliupelyte E., Lazauskas S., Matusevicius K., Vaisvila Z. 1986. The dependence of winter wheat yield and the efficacy of nitrogen fertilizers on the amount of mineral nitrogen in soil in Lithuanians conditions. Agrochimija, 10: 44-51 (in Russian)

Rutkowska A., Fotyma M. 2009. Calibration of soil test for mineral nitrogen in Poland. Communication in Soil Science and Plant Analysis. 40: 1-6 http://dx.doi.org/10.1080/00103620802695115

Staugaitis G., Vaisvila Z., Mazvila J., Arbaciauskas J., Adomaitis T., Fullen M. A. 2007. Role of soil mineral nitrogen foragricultural crops: nitrogennutrition diagnostics in Lithuania. Archives of Agronomy and Soil Science. 53: 263-271 http://dx.doi.org/10.1080/03650340701223338

Staugaitis G., Mažvila J., Vaišvila Z., Arbačiauskas J., Dalangauskienė A., Adomaitis T. 2008. Mineral nitrogen in Lithuanian soils. Žemès ūkio mokslai, 15 (3): 59-66 (in Lithuanian)

Stokes D.T., Sylvester-Bradley R., Scott R. K., Clare R., Hopkinson J., Milford C. F. J., Salmon S. E. 1998. An integrated approach to nitrogen nutrition for wheat. Project Report No. 159, Home Grown Cereals Authority HGCA, London, UK

Wang Qi, Li F., Zhang E., Li G., Vance M. 2012. The effects of irrigation and nitrogen application rates on yield of spring wheat (longfu-920), and water use efficiency and nitrate nitrogen accumulation in soil. Australian Journal of Crop Science, 6: 662-672

ISSN 1392-3196 / e-ISSN 2335-8947

Zemdirbyste-Agriculture, vol. 101, No. 2 (2014), p. 133-138

DOI 10.13080/z-a.2014.101.017

\title{
Mineralinio azoto kiekio įvairiuose dirvožemio sluoksniuose sąsajos Lietuvos žemès ūkio naudmenose
}

\author{
J. Arbačiauskas, G. Staugaitis, Z. Vaišvila, J. Mažvila, T. Adomaitis, D. Šumskis, \\ L. Žičkienè, J. Lubyte, R. Mažeika
}

Lietuvos agrarinių ir miškų mokslų centro Agrocheminių tyrimų laboratorija

\section{Santrauka}

Dirvožemio ėminių paèmimui iš gilesnių sluoksnių reikia daug darbo sąnaudų, todèl, siekiant jas sumažinti, buvo tirtas mineralinio azoto $\left(\mathrm{N}_{\min }\right)$ kiekio dirvožemio 0-60 ir 0-90 cm sluoksniuose priklausomumas nuo jo kiekio 0-30 $\mathrm{cm}$ sluoksnyje, kad dirvožemio azotingumą gilesniuose sluoksniuose būtų galima prognozuoti pagal paviršinị sluoksnị. Tyrimai atlikti 2009-2012 m. šalies 63-jų vietovių 156-iose $20 \times 20$ m dydžio stebėsenos aikštelèse, parinktose vyraujančiuose skirtingos granuliometrinès sudèties dirvožemiuose: Rytų Lietuvoje - smèlžemiuose (SD) ir palvažemiuose (PL) - smèlio, išplautžemiuose (ID) ir balkšvažemiuose (JI) - priesmèlio ir lengvo priemolio; Vidurio Lietuvoje - rudžemiuose (RD) ir išplautžemiuose (ID) - lengvo, vidutinio sunkumo, sunkaus priemolio ir molio; Vakaru Lietuvoje - priesmèlio ir lengvo priemolio balkšvažemiuose (JI) bei išplautžemiuose (ID). Tuo tikslu buvo panaudoti ir ilgalaikio tręšimo bandymo, vykdomo Vidurio Lietuvos lengvo priemolio rudžemyje, tyrimų duomenys. Mineralinio azoto kiekiui nustatyti èminiai buvo imti iš dirvožemio 0-30, 30-60 ir 60-90 cm sluoksnių. Nustatyta, kad daugiau azoto buvo sunkesnès granuliometrinès sudèties, taip pat $90 \mathrm{~kg} \mathrm{ha}^{-1}$ ir didesnèmis vienkartinèmis normomis azoto trą̌su tręštų laukelių dirvožemyje. Gauti esminiai koreliaciniai ryšiai tarp $\mathrm{N}_{m}$ kiekio dirvožemio $0-60$ arba $0-90 \mathrm{~cm}$ sluoksniuose su jo kiekiu $0-30 \mathrm{~cm}$ sluoksnyje: pavasarị atitinkamai $r^{2}=$ $0,837, P<0,01$ ir $r^{2}=0,687, P<0,01$, rudeni $-r^{2}=0,833, P<0,01$ ir $r^{2}=0,723, P<0,01$. Apskaičiuota $\mathrm{N}_{\text {min. }}$ kiekio sąsajos šiuose dirvožemio sluoksniuose, kurių reikšmės priklausė nuo $\mathrm{N}_{\min .}$ kiekio $0-30 \mathrm{~cm}$ sluoksnyje. Jam padidejjus nuo 6 iki $12 \mathrm{mg} \mathrm{kg}^{-1}, \mathrm{~N}_{\text {min. }}$ kiekio dirvožemio $0-60$ ir 0-30 cm sluoksniuose santykis pavasarị sumažèjo nuo $0,85 \pm 0,25$ iki $0,75 \pm 0,13$, rudeni - nuo $0,87 \pm 0,21$ iki $0,82 \pm 0,17$. Taikant regresijos lygtis arba šiuos santykius, $\mathrm{N}_{\min }$ kiekius gilesniuose dirvožemio sluoksniuose galima apskaičiuoti pagal jo kiekį $0-30 \mathrm{~cm}$ sluoksnyje. Taip pat nustatyti glaudūs koreliaciniai ryšiai tarp nitratinio bei mineralinio azoto kiekio pavasarị ir rudeni dirvožemio 0-60 bei $0-90 \mathrm{~cm}$ sluoksniuose ir apskaičiuotos jų santykinès reikšmès. Mineralinio azoto kiekiui dirvožemyje didèjant, jo sudètyje santykinai daugiau padidèja nitratų kiekis.

Reikšminiai žodžiai: dirvožemis, ėminių gylis, $\mathrm{N}_{\text {min. }}, \mathrm{N}^{-\mathrm{NO}_{3}}$, tręšimas. 